\title{
O USO DO HIDRÓXIDO DE CÁLCIO PARA APICIFICAÇÃO: RELATO DE UM CASO CLÍNICO
}

Alex HUBER, Maria Izabel FARIA, Egas Moniz de ARAGÃO, Marcos INVERNICI, Alexandre Roberto HECK

O objetivo deste trabalho é relatar um caso clínico de apicificação com o uso do hidróxido de cálcio. Paciente ECF, sexo masculino, 8 anos, compareceu ao atendimento odontológico buscando solução para uma fratura envolvendo esmalte e dentina no elemento dentário 21, observada durante o exame clínico. O responsável pelo paciente relatou que o dente fraturou após um trauma. A resposta aos testes de vitalidade pulpar foi negativa e no exame radiográfico observou-se que o dente apresentava rizogênese incompleta. Foi realizada assepsia do local, isolamento absoluto, assepsia do campo operatório, abertura coronária, preparo químico-mecânico tendo como substância auxiliar da instrumentação o hipoclorito de sódio a 1\% e realizada medicação intra-canal com hidróxido de cálcio. Após 2, 3 e 5 meses foram realizados acompanhamentos radiográficos e troca da medicação. Após a última troca o paciente retornou somente após um ano, e nesta ocasião durante a troca do hidróxido de cálcio foi constatada a formação da barreira apical mineralizada. Uma semana após foi realizada a obturação do canal radicular adaptando-se inicialmente o cone principal por moldagem e executou-se a obturação pela técnica híbrida de Tagger. Concluiu-se, que o uso do hidróxido de cálcio continua sendo uma excelente alternativa para a realização da apicificação.

Palavras chave: Endodontia, Preparo do Canal Radicular, Hidróxido de cálcio. 